\title{
Article \\ The Österplana Fossil Meteorites and... What Else? Terrestrial Cr-Spinels and Zircons in the Ordovician Limestones of the Thorsberg Quarry (Sweden)
}

\author{
Davide Lenaz $1, *\left(\mathbb{B}\right.$, , Matteo Velicogna ${ }^{1,2}$, Maurizio Petrelli ${ }^{3}\left[\right.$ and Birger Schmitz ${ }^{4}$ \\ 1 Department of Mathematics and Geosciences, University of Trieste, 34128 Trieste, Italy; \\ matteo.velicogna@unipd.it \\ 2 Department of Territory and Agro-Forestry Systems, University of Padua, 35020 Legnaro, Italy \\ 3 INFN, Sezione di Perugia, 06123 Perugia, Italy; maurizio.petrelli@unipg.it \\ 4 Astrogeobiology Laboratory, Department of Physics, Lund University, 22100 Lund, Sweden; \\ birger.schmitz@nuclear.lu.se \\ * Correspondence: lenaz@units.it
}

Citation: Lenaz, D.; Velicogna, M.; Petrelli, M.; Schmitz, B. The Österplana Fossil Meteorites and... What Else? Terrestrial Cr-Spinels and Zircons in the Ordovician Limestones of the Thorsberg Quarry (Sweden). Geosciences 2022, 12, 54. https:// doi.org/10.3390/geosciences 12020054

Academic Editors: Andrew C. Morton, Shane Tyrrell, Gustavo Zvirtes and Jesus Martinez-Frias

Received: 21 December 2021

Accepted: 19 January 2022

Published: 24 January 2022

Publisher's Note: MDPI stays neutral with regard to jurisdictional claims in published maps and institutional affiliations.

Copyright: (C) 2022 by the authors. Licensee MDPI, Basel, Switzerland. This article is an open access article distributed under the terms and conditions of the Creative Commons Attribution (CC BY) license (https:// creativecommons.org/licenses/by/ $4.0 /)$.

\begin{abstract}
In the Ordovician limestone of the Thorsberg quarry (South Sweden), about 130 meteorites have been found. Among the extraterrestrial material, several terrestrial Cr-spinels and zircons have been found too. In particular, in the interval 416-447 cm above the Arkeologen bed, terrestrial Cr-spinels, compositionally different from previous studied Cr-spinels of the same sequence, are present. Previous studies on zircon provided depositional ages that range from $464.22 \pm 0.37 \mathrm{Ma}$ to $465.01 \pm 0.26 \mathrm{Ma}$. The trace element content of zircons suggests different possible source rocks. In fact, zircons from the oldest ash layer resemble those from dolerite, while those in the youngest layers are similar to zircons commonly found in granitoids, with more than $65 \% \mathrm{wt}$. $\mathrm{SiO}_{2}$. The chemistry of $\mathrm{Cr}$-spinels suggests a strong alteration, so that it is difficult to assign them to a specific area, however they recall the chemistry of altered spinels from ophiolitic occurrences (among other possibilities). The geological setting of the Laurentia and Baltica areas, including the description of basalts to rhyolite association and the presence of ophiolitic slices, makes us confident about the derivation of these zircons and Cr-spinels from those areas.
\end{abstract}

Keywords: Cr-spinel; zircon; Ordovician; Sweden; Laurentia; Baltica

\section{Introduction}

About a quarter of all meteorites falling on Earth today originate from the breakup of the L-chondrite parent body $\sim 466 \mathrm{Ma}$ ago, the largest documented breakup in the asteroid belt in the past $\sim 3 \mathrm{Ga}$. A systematic search for fossil meteorites was initiated in the Thorsberg quarry in southern Sweden in the 1990s [1,2]. In the quarry, since then, about 130 meteorites, 1-21 cm in diameter, have been found. The meteorites fell over an area of less than ca. 30,000 $\mathrm{m}^{2}$ of the seafloor during $\sim 2 \mathrm{Ma}$. About 100 of the recovered meteorites have been analysed for chrome-spinel composition and classified so far [3]. All except one of these are ordinary chondrites, and are almost certainly L chondrites, based on the more detailed oxygen isotope and chondrule-size studies of a representative subset of fossil meteorites [4-6]. One of the recovered meteorites, once called Mysterious Object (now Österplana 065), is an $8 \mathrm{~cm}$ winonaite-related meteorite of a type not known among present-day meteorite falls and finds [7]. The Österplana 065 seems to be a fragment of the impactor that broke up the L-chondrite parent body that, according to [8], was shown to be the first documented example of a meteorite type that does not fall on Earth today, because its parent body has been consumed by collisions. In the sediments containing fossil meteorites, there are also abundant L-chondritic chromite grains [9].

The Österplana 065 was found in the Glaskarten 3 bed that spans the interval from $427-467 \mathrm{~cm}$ above the base of the Arkeologen bed. In the same interval $(416-447 \mathrm{~cm})$, 
the so-called Mysterious Layer (ML), characterized by exceptionally high concentrations of Cr-spinel grains, can be found. The Cr-spinels of the Österplana 065 have nothing in common with the $\mathrm{Cr}$-spinels from the ML that are terrestrial. Moreover, the chemistry of the terrestrial $\mathrm{Cr}$-spinels of ML is very different from that of the other terrestrial $\mathrm{Cr}$-spinels in the rest of the section, and occurring in the same levels as zircons.

Zircons from different ash-bearing layers provide stratigraphically consistent depositional ages that range from $464.22 \pm 0.37 \mathrm{Ma}$ to $465.01 \pm 0.26 \mathrm{Ma}$ [10].

Among the several heavy minerals that can be found in sediments, $\mathrm{Cr}$-spinel is of particular significance because, unlike silicate minerals, it is resistant to low-grade alteration and mechanical breakdown. Furthermore, it is a widespread accessory mineral in rocks that are potential sources of sediments as ultramafic intrusive, cumulate and volcanic suites, or metamorphic rocks (see review in [11,12]). When derived from mantle peridotites and primitive rocks, this is indicative of magmatic and tectonic evolution in the source areas [13-19]. Spinel chemistry is diagnostic of parental melt composition and crystallisation conditions $[11,12,20,21]$, and it often contains melt inclusion carrying direct information on magma chemistry $[12,17,22-24]$.

Zircon forms in a wide variety of igneous and metamorphic rocks, as they are ultrastable, are often used in paleogeographic reconstruction for single-grain $\mathrm{U}-\mathrm{Pb}$ dating. However, [25-27], among others, they showed that zircon displays variations in trace elements that could reflect host rock compositions, the most significant being those related to REE, U, Th, Y, and Nb. Owen (1987) [28] suggested the Hf content as a possible discriminant in provenance. Metamorphic zircons can be distinguished by magmatic ones according to $\mathrm{Th} / \mathrm{U}$ ratios [29-31].

Here, we will study the chemistry of both spinels and zircons found in the Ordovician limestones of the Thorsberg quarry, trying to estimate their possible provenance.

\section{Geological Setting}

In 1993, following two finds of fossil meteorites in mid-Ordovician marine limestone in Sweden, a systematic search for meteorites was initiated in the Thorsberg quarry in southern Sweden [1,2]. During most of the Ordovician, this area was situated several hundreds of kilometres from the mainland, and constituted a tectonically stable depositional environment. The lithified sediments formed slowly, $2-4 \mathrm{~mm} \mathrm{Ka}^{-1}$. It is in the industrial process of limestone extraction that the meteorites are recovered, and until today, that the around 130 meteorites have been found, representing 98\% of all fossil meteorites known to science. Although the recovered meteorites fell during $\sim 2 \mathrm{Ma}$, the limestone beds being sawed and yielding meteorites, however, represent $<1$ Ma of time [1].

\section{Materials and Methods}

A total of $1320 \mathrm{~kg}$ of limestone samples (about 50 rock pieces) from the HällekisThorsberg section were processed at the Astrogeobiology Laboratory at Lund University, using techniques developed for the separation and extraction of extraterrestrial minerals from sediments [2]. The sample depths range from -6.18 to $+10.30 \mathrm{~m}[2,9]$ relative to the base of the Arkeologen bed, with no visible bentonite layer identified (Figure 1). The bulk samples were dissolved in $\mathrm{HCl}(6 \mathrm{M})$ and $\mathrm{HF}(11 \mathrm{M})$ at room temperature after thorough cleaning (see [9], for details). After sieving at mesh sizes 32 and $63 \mu \mathrm{m}$, residues were carefully searched under the binocular microscope for chrome-spinel and zircon grains. Only samples from three levels, i.e., +1.80 to $+1.90 \mathrm{~m}$ (Likhall), +4.18 to $+4.35 \mathrm{~m}$ (HKIS 4c), and +5.09 to $+5.26 \mathrm{~m}$ (HKIS 2a) contained well-preserved zircons with a likely volcanic ash origin; a lower layer seemingly not related to ash is also present (No Ash).

Zircons are colourless, euhedral grains of up to $500 \mu \mathrm{m}$ in length. They are elongated to acicular morphologies, with aspect ratios greater than 3 , and have well-defined crystal faces and sharp edges, with no signs of transport abrasion. According to [32,33], these zircons are probably from volcanic ash or tuff, as they show no signs of transport 
abrasion, and share common features with the elongated acicular morphologies typical of rapid crystallization.

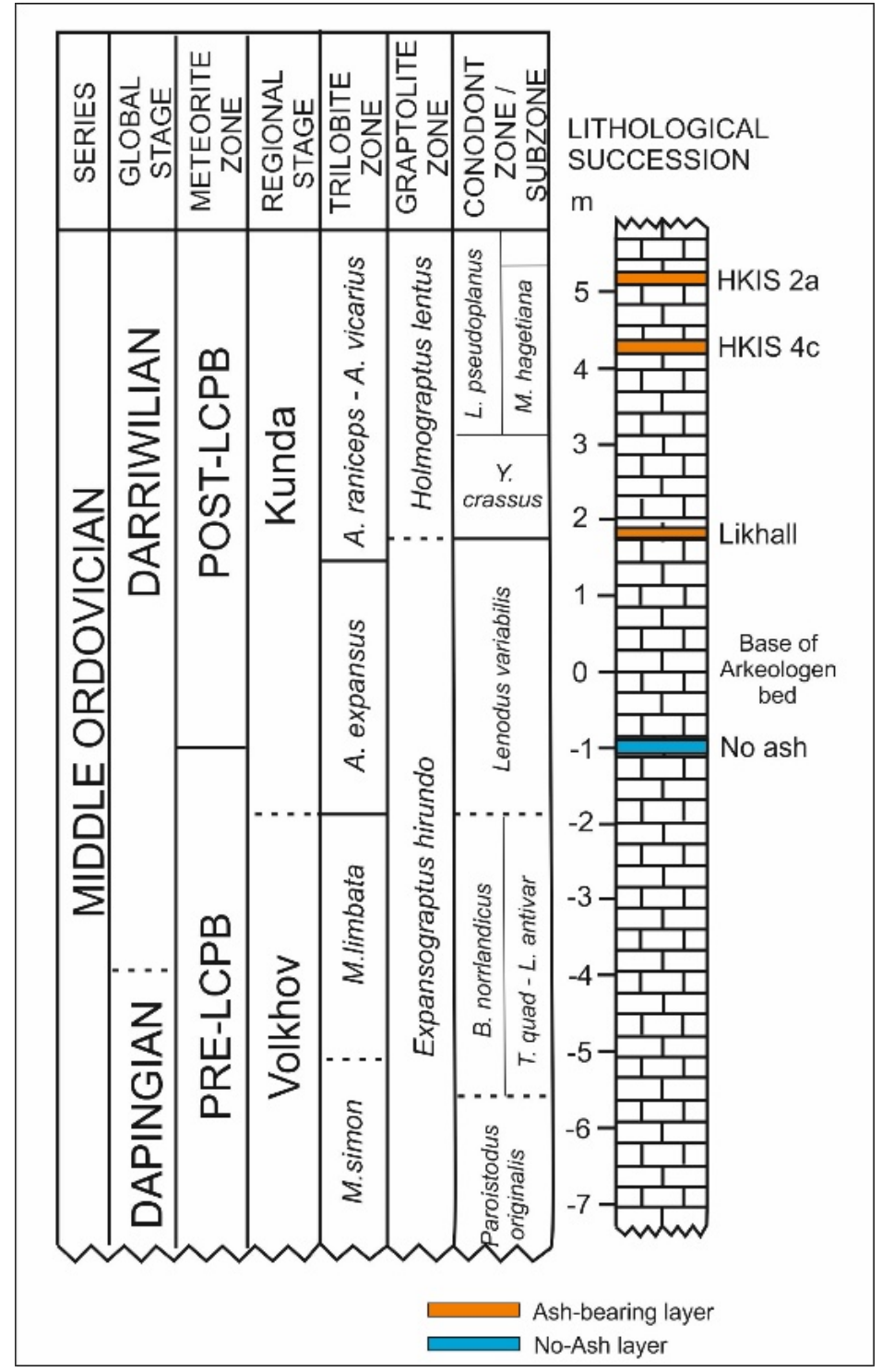

Figure 1. Stratigraphic column.

The grains were mounted in epoxy, polished flat with 6 and $1 \mu \mathrm{m}$ diamond paste, and coated with carbon. Elemental composition was determined with an INCA Oxford systems energy dispersive X-ray device (EDS) attached to a Hitachi S-3400N scanning electron microscope (SEM) at the Department of Geology, Lund University. Electron voltage was set to $15 \mathrm{keV}$ and working distance to $10 \mathrm{~mm}$. Counting time was set to $60-80 \mathrm{~s}$ per analysis. For the standardization of the instrument, a cobalt standard was used. For the standardization of the spectrum peaks, we used synthetic pure spinel for $\mathrm{Mg}$ and $\mathrm{Al}$, chromite for $\mathrm{Cr}$, hematite for $\mathrm{Fe}$, and titanite for Ti. Analytical accuracy was controlled by the USNM 117075 (Smithsonian) reference standard [34].

In situ chemical analyses on zircons have been performed by the LA-ICP-MS (Laser Ablation Inductively Coupled Plasma Mass Spectrometry) hosted by the Department of Physics and Geology of the University of Perugia. The laser ablation device was a Teledyne/Photon Machine G2 (ATL-I-LS-R solid state-triggered excimer $193 \mathrm{~nm}$ laser) equipped with a two-volume ANU (Australian National University) HelEx 2 cell. The spectrometer was a quadrupole Thermo Fisher Scientific iCAP Qc ICP-MS. The analytical 
setup and relative figures of merit (precision, accuracy, and detection limits) are described in $[35,36]$. The spot size for all the analyses has been set at $12 \mu \mathrm{m}$, and helium has been used as carrier. The zircon trace elements $\left({ }^{31} \mathrm{P},{ }^{42} \mathrm{Ca},{ }^{47} \mathrm{Ti},{ }^{55} \mathrm{Mn},{ }^{57} \mathrm{Fe},{ }^{71} \mathrm{Ga},{ }^{85} \mathrm{Rb},{ }^{89} \mathrm{Y},{ }^{90} \mathrm{Zr}\right.$, ${ }^{93} \mathrm{Nb},{ }^{118} \mathrm{Sn},{ }^{137} \mathrm{Ba},{ }^{139} \mathrm{La},{ }^{140} \mathrm{Ce},{ }^{141} \mathrm{Pr},{ }^{146} \mathrm{Nd},{ }^{147} \mathrm{Sm},{ }^{153} \mathrm{Eu},{ }^{157} \mathrm{Gd},{ }^{159} \mathrm{~Tb},{ }^{163} \mathrm{Dy},{ }^{165} \mathrm{Ho},{ }^{166} \mathrm{Er}$, ${ }^{169} \mathrm{Tm},{ }^{173} \mathrm{Yb},{ }^{175} \mathrm{Lu},{ }^{178} \mathrm{Hf},{ }^{181} \mathrm{Ta},{ }^{208} \mathrm{~Pb},{ }^{232} \mathrm{Th}$ and ${ }^{238} \mathrm{U}$ ) have been analysed using the reference standard STD 91500, and following the method suggested by [37].

\section{Results and Discussions}

\subsection{Cr-Spinels}

The analysed spinels are essentially chromites in composition. The $\mathrm{Cr}_{2} \mathrm{O}_{3}$ amount is usually high; in fact, more than $75 \%$ of the studied spinels present $\mathrm{Cr}_{2} \mathrm{O}_{3}$ higher than 30 wt. \% (Figure 2). It is followed by iron that, in the FeO form, usually comprises from 20-30 wt. \% (about 85\% in frequency), while in the $\mathrm{Fe}_{2} \mathrm{O}_{3}$ form (calculated according to stoichiometry), it is variable with the highest frequency $20-40 \mathrm{wt}$. \% (more than $75 \%$ of the analysed spinels fall into this field). About $90 \%$ of the spinels have an $\mathrm{Al}_{2} \mathrm{O}_{3}$ content lower than $5 \mathrm{wt}$. \%, while $\mathrm{MgO}$ is usually below $5 \mathrm{wt}$. \% (about $85 \%$ of the spinels). Apart from a couple of samples, $\mathrm{TiO}_{2}$ is below 3 wt. $\%$, $\mathrm{MnO}$ below 0.35 wt. $\%$ and $\mathrm{V}_{2} \mathrm{O}_{3}$ below $0.5 \mathrm{wt}$. \%.
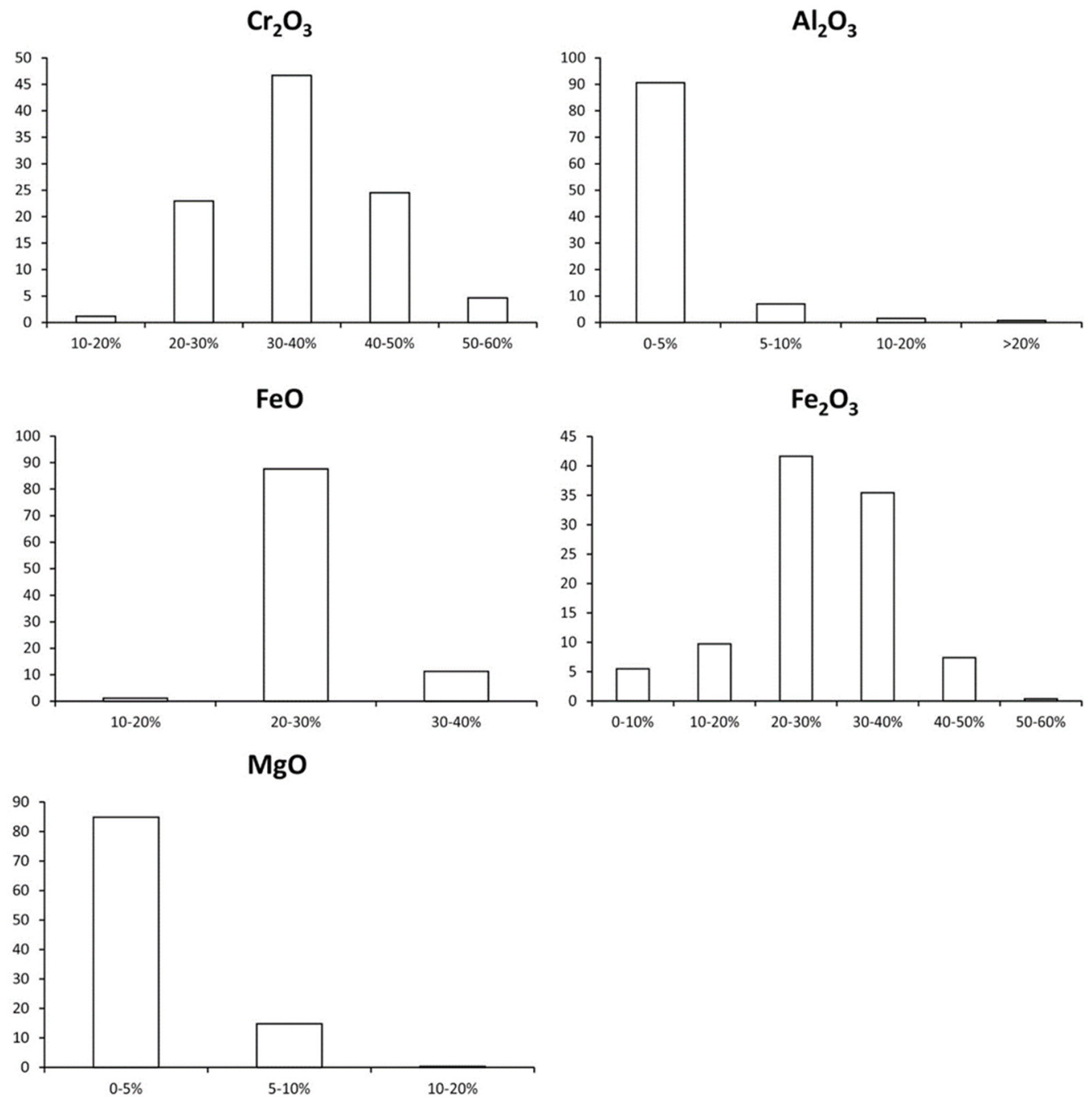

Figure 2. Frequency distribution of $\mathrm{Cr}_{2} \mathrm{O}_{3}, \mathrm{Al}_{2} \mathrm{O}_{3}, \mathrm{FeO}, \mathrm{Fe}_{2} \mathrm{O}_{3}$, and $\mathrm{MgO}$ in the studied spinels.

Commonly, detrital spinels are related to ophiolitic material. Lenaz et al. (2000) [17] and [12] provided the spinel $\mathrm{TiO}_{2}$ vs. $\mathrm{Al}_{2} \mathrm{O}_{3}$ diagram (Figure 3). This diagram allows the discrimination of ophiolitic spinels from different tectonic settings, such as island arc, ocean island, back-arc basin, and MORB. The studied spinels show compositions 
different from any represented field. In the same figure, the composition of Cr-spinels from the Shetland, Ballantrae, and Leka ophiolites is also represented. The composition of the detrital Cr-spinels found in Kinnekulle resembles that of the ferrianchromite rims of $\mathrm{Cr}$-spinels from those ophiolites, but the detritals are usually richer in $\mathrm{TiO}_{2}$. This fact,

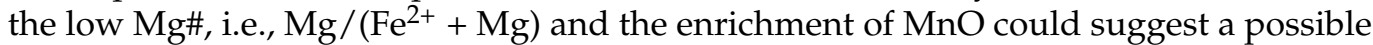
secondary process [38].

Alwmark and Schmitz (2007) [39] noticed that in extraterrestrial chromites from the Lockne crater in central Sweden, there were Zn enrichment and oxidation. They suggested that it was a result of the hydrothermal system induced by the impact. However, the extraterrestrial $\mathrm{Cr}$-spinels from Kinnekulle are not considered altered, due to the absence of Zn enrichment [40].

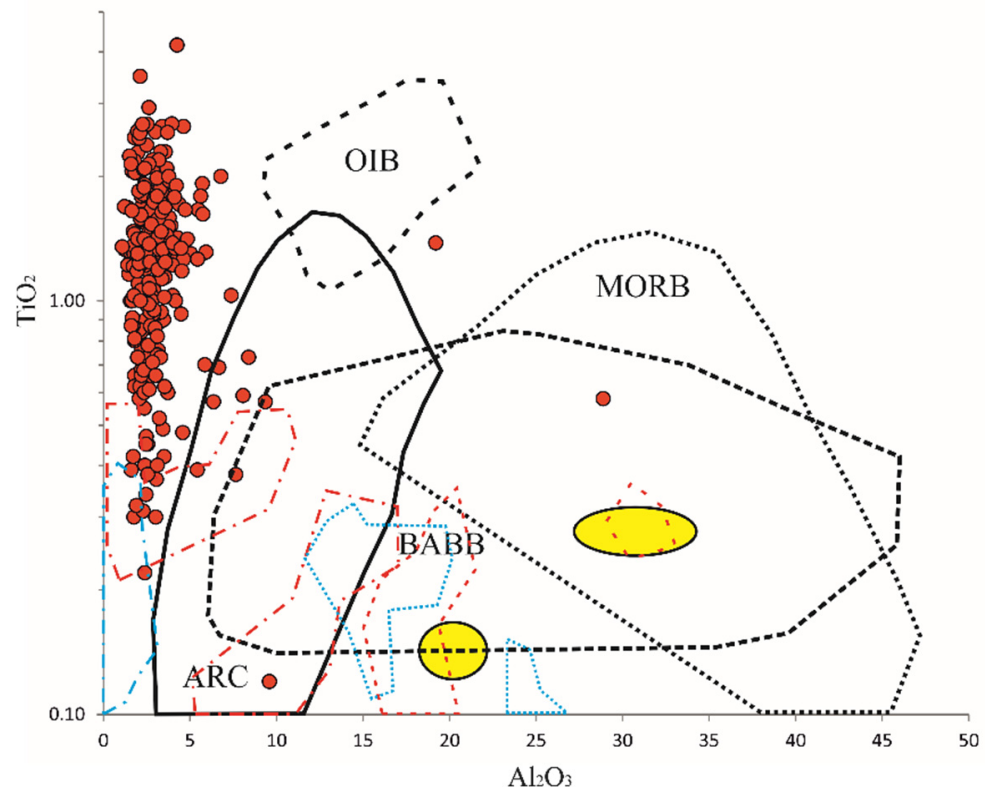

Figure 3. $\mathrm{TiO}_{2}$ vs. $\mathrm{Al}_{2} \mathrm{O}_{3}$ diagram. Red circles: Cr-spinels from Kinnekulle (this study); yellow fields: Cr-spinels from Ballantrae ophiolites [41]; red dotted lines: Cr-spinels from Shetland ophiolites [42]; red dot and dash lines: ferrian-chromite rims of Cr-spinels from Shetland ophiolites [42]; blue dotted lines: Cr-spinels from Leka ophiolites [43]; blue dot and dash lines: ferrian-chromite rims of Cr-spinels from Leka ophiolites [43]. Fields for Arc, OIB (ocean island basalts), BABB (back arc basin Basalts), and MORB (mid ocean ridge basalts) after [12,19].

According to the chemical compositions, the $\mathrm{Cr \# ,} \mathrm{i.e.,} \mathrm{Cr} /(\mathrm{Cr}+\mathrm{Al})$, is in the range 0.78-0.94 for the majority of spinels, while the Fe\#, i.e., $\mathrm{Fe}^{2+} /\left(\mathrm{Fe}^{2+}+\mathrm{Mg}\right)$, is in the range 0.67-0.97. The $\mathrm{Fe}^{3+} /\left(\mathrm{Fe}^{3+}+\mathrm{Al}+\mathrm{Cr}\right.$ ) is usually higher than 0.2 (maximum 0.7 ). This value is particularly interesting because, in meteoritic spinels, the $\mathrm{Fe}^{3+}$ is virtually absent, so that it allows the possibility to discriminate between terrestrial and extraterrestrial occurrences.

To understand the likely provenance for these spinels, we compared them with the database of [11]. If we consider the Cr\# vs. Mg\# diagram, our spinels fall into the field or close to the field of alkali basalts, lamprophyres, and related rocks and worldwide Alaskan zoned ultramafic complexes (Figure 4). Anyway, they differ from the closest Alaskan complexes of the Urals, that, by the way, are also younger, showing a comparable Cr\# in the range $0.60-0.85$, but lower Fe\# in the range $0.2-0.8[44,45]$. When inserted into the ternary $\mathrm{Cr}-\mathrm{Fe}^{3+}-\mathrm{Al}$ diagram, they perfectly fall into the field of alkali basalts, lamprophyres, and related rocks, and are similar to the worldwide Alaskan ultramafic complexes [11] (Figure 5). However, we were unable to find source areas with similar compositions. 


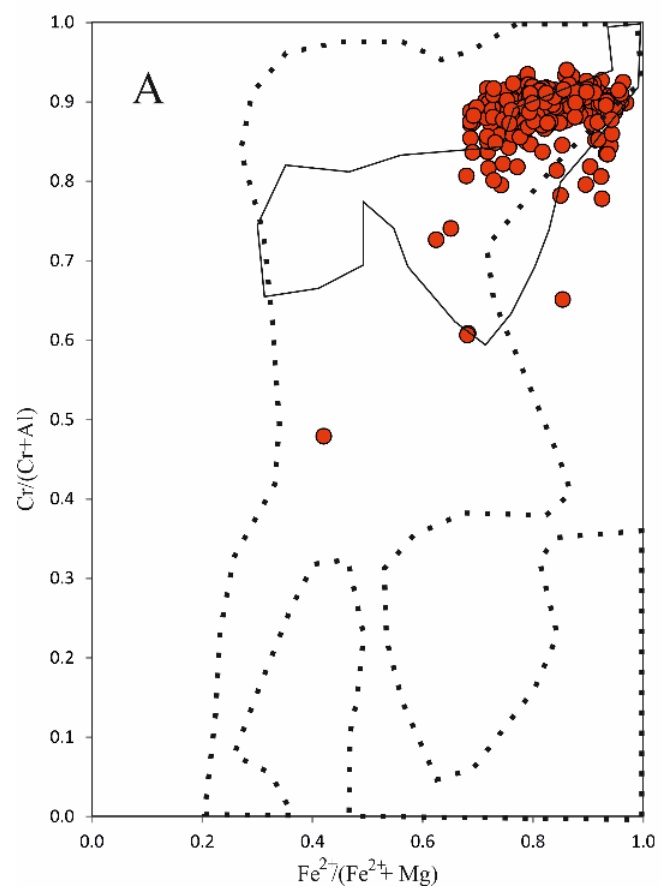

Figure 4. $\mathrm{Cr} /(\mathrm{Cr}+\mathrm{Al})$ vs. $\mathrm{Fe}^{2+} /\left(\mathrm{Fe}^{2+}+\mathrm{Mg}\right)$ for the spinels and alkaline basalts studied here; lamprophyres, related rocks [11] (dotted line), and Alaskan ultramafic complexes [11] (continuous line).

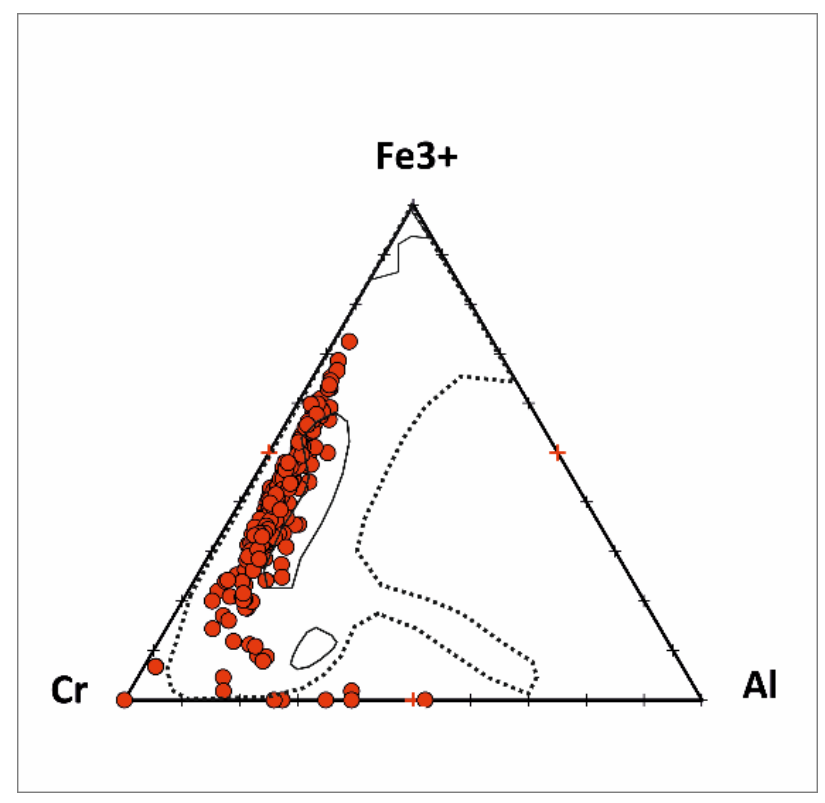

Figure 5. $\mathrm{Cr}_{-} \mathrm{Fe}^{3+}-\mathrm{Al}$ ternary diagram for the spinels and alkaline basalts studied here; lamprophyres, related rocks [11] (dotted line), and Alaskan ultramafic complexes [11] (continuous line).

In the Scandinavian area, there are scattered occurrences of chromites and/or Cr-spinels. Among other things, in central Sweden, chromites occur in the Proterozoic metallogenic province of Bergslagen [46], in the Kittelfjäll spinel peridotite; a fragment of lithospheric mantle, which occurs as an isolated body within high grade metamorphic crustal rocks of the Seve Nappe Complex [47]. In Norway, they are usually associated with ophiolites, as in the case of Leka $[43,48]$, while in Finland, they occur in Paleoproterozoic primitive volcanic rocks [49], or in layered deposits such as Kemi [50]. Other ophiolites related to the closure of the Iapetus can be found in Newfoundland [51,52]. Anyway, none of these occurrences fit our analyses. Considering that their chemistry is similar to the one of the altered rims of Shetland and Leka ophiolites [42,43], they may be the product of alteration of an ophiolitic 
segment, or they could be supplied as an aeolian contribution, as happened, for example, for spinels in the Maiolica formation in Italy [53], deriving from unknown alkaline basalt, lamprophyre, or Alaskan ultramafic occurrences.

\subsection{Zircons}

In zircons, Hf and $\mathrm{Y}$, which can be considered as minor elements for zircons, are in the ranges 5800-20,000 ppm and 100-7200 ppm, respectively. In particular, Hf is in the range 5800-14,700 ppm for the No Ash sample (mean $9195 \pm 2329), 7860-12,500$ ppm for LIK (mean 9626 \pm 992), 6300-18,900 ppm for 4C (mean $9693 \pm 1769$ ), and 8600-20,260 ppm for $2 \mathrm{~A}$ (mean 12,351 \pm 2597 ). Yttrium is in the range 260-2220 ppm for the No Ash sample (mean $1029 \pm 510)$, 540-2800 ppm for LIK (mean $1711 \pm 601)$, 104-5300 ppm for 4C (mean $2562 \pm 1058$ ), and 1060-7170 ppm for 2A (mean $2717 \pm 1347)$. The ionic radius of $\mathrm{Zr}$ is most closely matched by the smaller radii HREE than the larger LREE, so that the abundances of HREE are larger than those of LREE [31]. Given this, the total content of LREE (La to Pr) is lower than about 100 ppm (No Ash: 4-34 ppm; LIK: 6-45 ppm; 4C: 9-103 ppm; 2A: 7-53 ppm), that of MREE (Nd to Gd) is lower than about $250 \mathrm{ppm}$ (No Ash: 8-41 ppm; LIK: 12-106 ppm; 4C: 7-248 ppm; 2A: 18-179 ppm), and that of HREE (Tb to Lu) is in the range 55-4055 (No Ash: 354-1922 ppm; LIK: 421-1972 ppm; 4C: 110-3865 ppm; 2A: 770-4288 ppm). The values of $\mathrm{P}$ can be very different in zircons according to the host rocks. This is in the range 59-2615 ppm for the studied zircons (No Ash: 125-814 ppm; LIK: 185-838 ppm; 4C: 59-1167 ppm; 2A: 418-2615 ppm). According to [31], Th and U are somewhat compatible with $\mathrm{Zr}$ (ionic radii: $\mathrm{Th}^{4+} 1.05 \AA, \mathrm{U}^{4+} 1.00 \AA$ ) and occur in crustal zircon with abundances typically ranging from tens- to thousands-of-ppm. Thorium is in the range 30-529 ppm for the studied zircons (No Ash: 50-263 ppm; LIK: 40-349 ppm; 4C: 38-529 ppm; 2A: 30-510 ppm), while U is in the range 57-447 ppm (No Ash: 144-383 ppm; LIK: 66-348 ppm; 4C: 57-377 ppm; 2A: 61-447 ppm).

To discriminate between possible sources, some provenance diagrams have been used. According to the Th vs. U diagram [31] (Figure 6), zircons with Th/U ratios lower than 0.1 are metamorphic, and those with values above 0.1 are magmatic, even if [54] suggested that recrystallized and newly grown metamorphic zircons often have high Th/U ratios. The zircons studied here show values close to or greater than 1, so they can be considered as magmatic. It is interesting to notice that all the occurrences of zircons show subparallel trends and those from the No Ash level are usually lower in Th for a given U content.

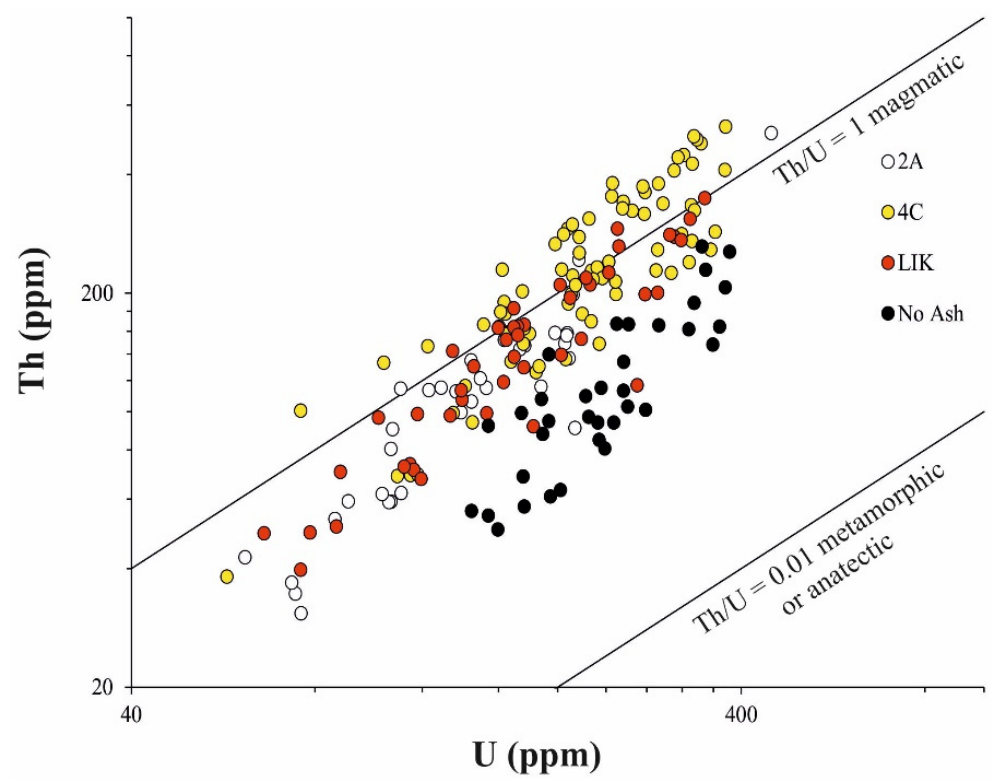

Figure 6. Th vs. U diagram for the here studied zircons, according to [31]. White circles: 2A; yellow circles: 4C; red circles: LIK; black circles: No Ash. 
Another effective method to discriminate between pristine magmatic zircons and the "metamorphic" ones is to verify their REE patterns, mainly focusing on HREE ratio $\left(\mathrm{Gd}_{\mathrm{CN}} / \mathrm{Yb}_{\mathrm{CN}}\right)$, and secondarily, $\mathrm{Ce}$ and $\mathrm{Eu}$ anomalies $[27,31,55,56]$. Generally, the analysed crystals show quite strong positive $\mathrm{Ce}$ and negative $\mathrm{Eu}$ anomalies, together with a steep HREE trend, typical of magmatic crystals (Figure 7). Only one zircon (4c-53) shows no $\mathrm{Eu}$ anomaly, and a slightly flatter $\mathrm{Gd}_{\mathrm{CN}} / \mathrm{Yb}_{\mathrm{CN}}$ ratio $\left(\mathrm{Gd}_{\mathrm{CN}} / \mathrm{Yb}_{\mathrm{CN}}=0.14\right)$ that could suggest an eclogitic origin [56]. Grimes et al. (2007) [57] divided oceanic (MORB) and continental zircons by using $\mathrm{U} / \mathrm{Yb}$ vs. $\mathrm{Hf}$ and $\mathrm{U} / \mathrm{Yb}$ vs. Y diagrams (Figure 8). These diagrams show that at least some of the zircons from the No Ash level present a MORB affinity. All the others are related to a continental arc. The same results can also be obtained by using the $\mathrm{U} / \mathrm{Yb}$ vs. $\mathrm{Nb} / \mathrm{Yb}$ [55] (Figure 9). Recently, to discriminate zircons from different tephras, [58] introduced some discriminant functions, taking into consideration several trace and rare earth elements in zircons. The applications of the so-called DF1 and DF2 parameters show that the No Ash level falls in a field different from the one where the other samples fall (Figure 10). Moreover, the Yb/Dy vs. Dy diagram is characterized by a relatively low $\mathrm{Yb}$ /Dy ratio and a wide variation in Dy consistent with dominant plagioclase crystallization accompanied with minor allanite, zircon, and amphibole fractionation for the No Ash, 4C and 2A levels, whereas the LIK zircons have high Yb/Dy ratios and limited Dy variation, which can be explained by dominant amphibole fractionation, in addition to plagioclase crystallization.

Different sources could also be differentiated by employing the $\mathrm{Gd}_{\mathrm{CN}} / \mathrm{Yb}_{\mathrm{CN}}$ vs. $\mathrm{Nb} / \mathrm{Yb}$ (Figure 11) diagram [55], which emphasizes the increase of garnet signature, zircon (cooling of the melt), and titanite-apatite-ilmenite crystallization. The investigated samples plot in a quite small area in which they partially overlap, but it is possible to recognize an increase in the garnet signature from No Ash-2a to Likhall, and finally, to 4c. However, if we consider the stratigraphic continuity, it is possible to imply that there was an increase of the garnet signature occurring from No Ash to Likhall, and then 4c. Successively, a fractionation of titanite-apatite-ilmenite in 2a occurred, plotting the sample near No Ash.

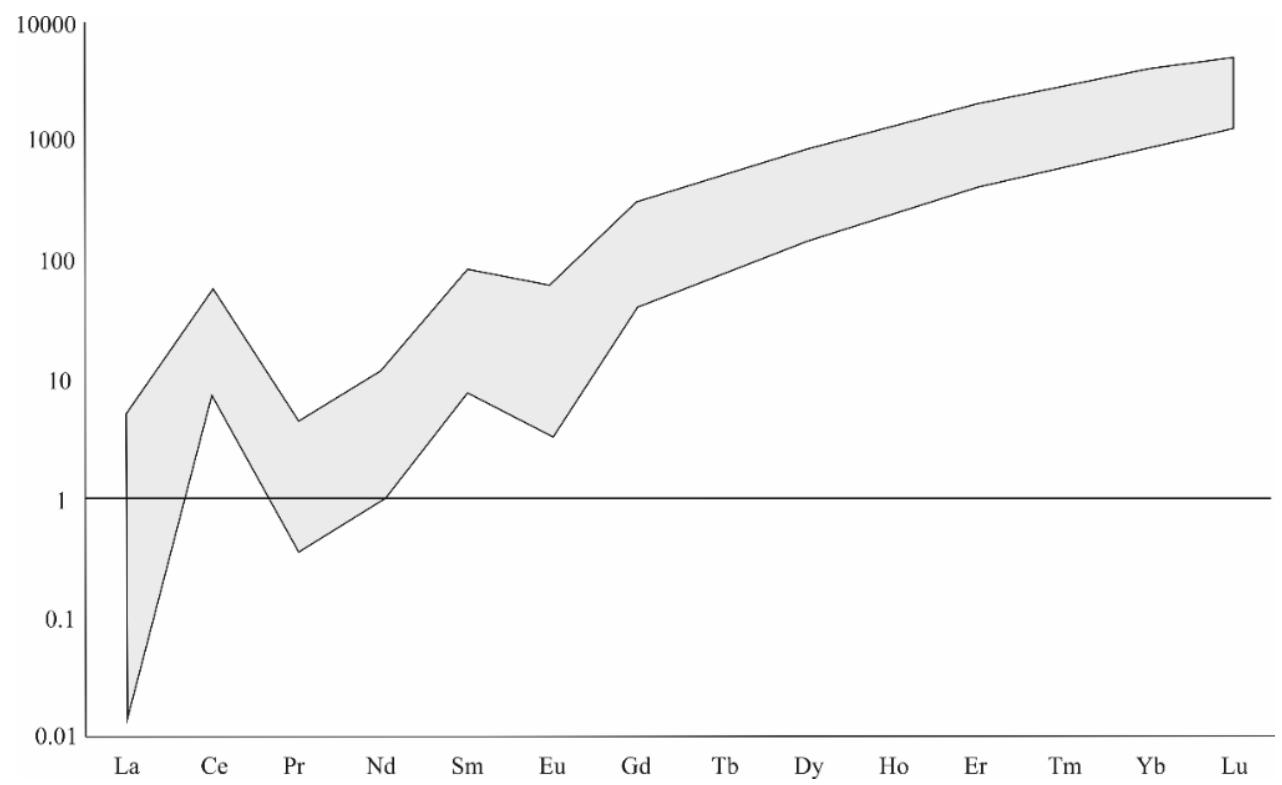

Figure 7. Range of REE content in the studied samples. 

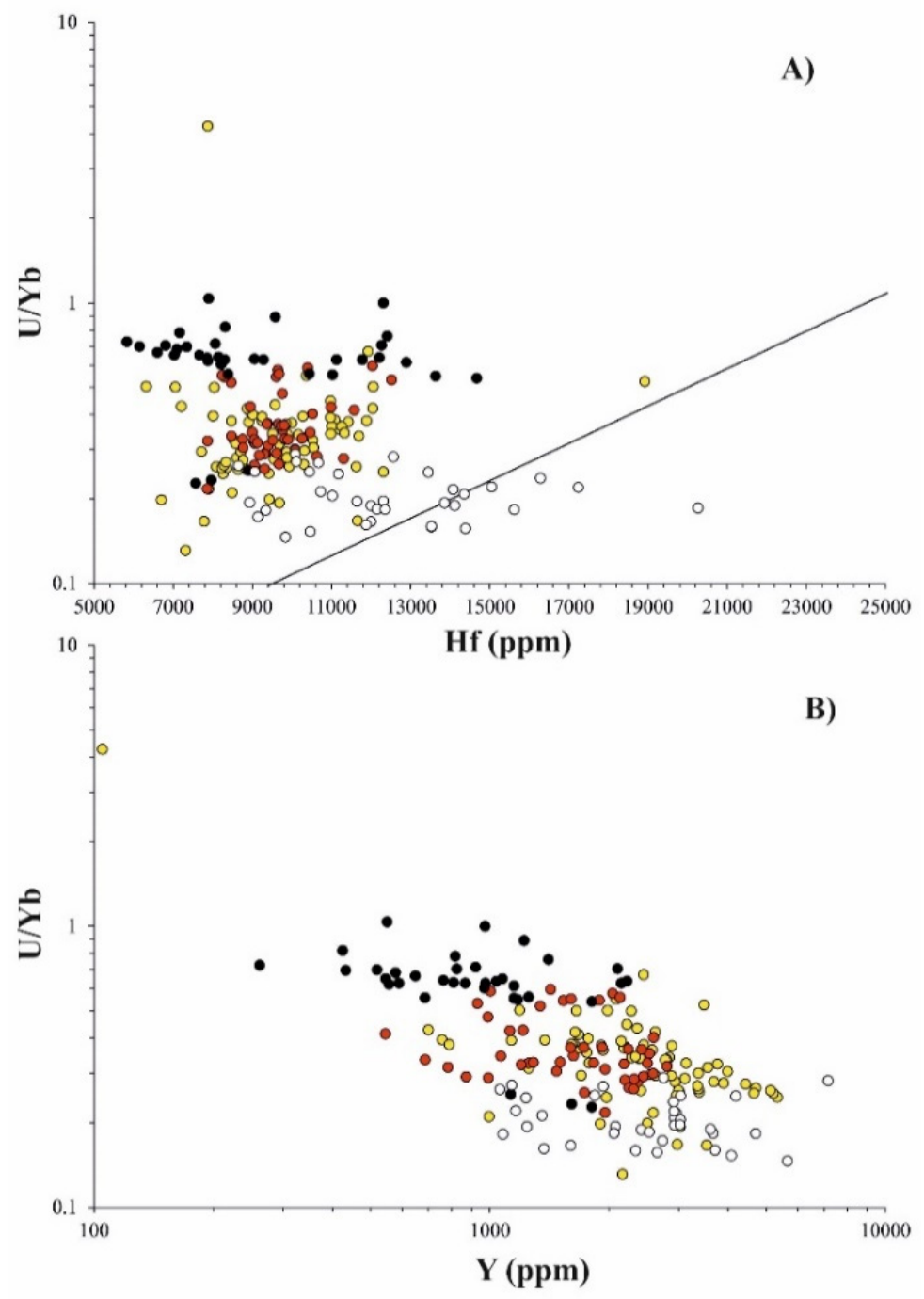

Figure 8. (A) U/Yb vs. Hf and (B) U/Yb vs. Y diagrams according to [57]. Symbols as in Figure 7.

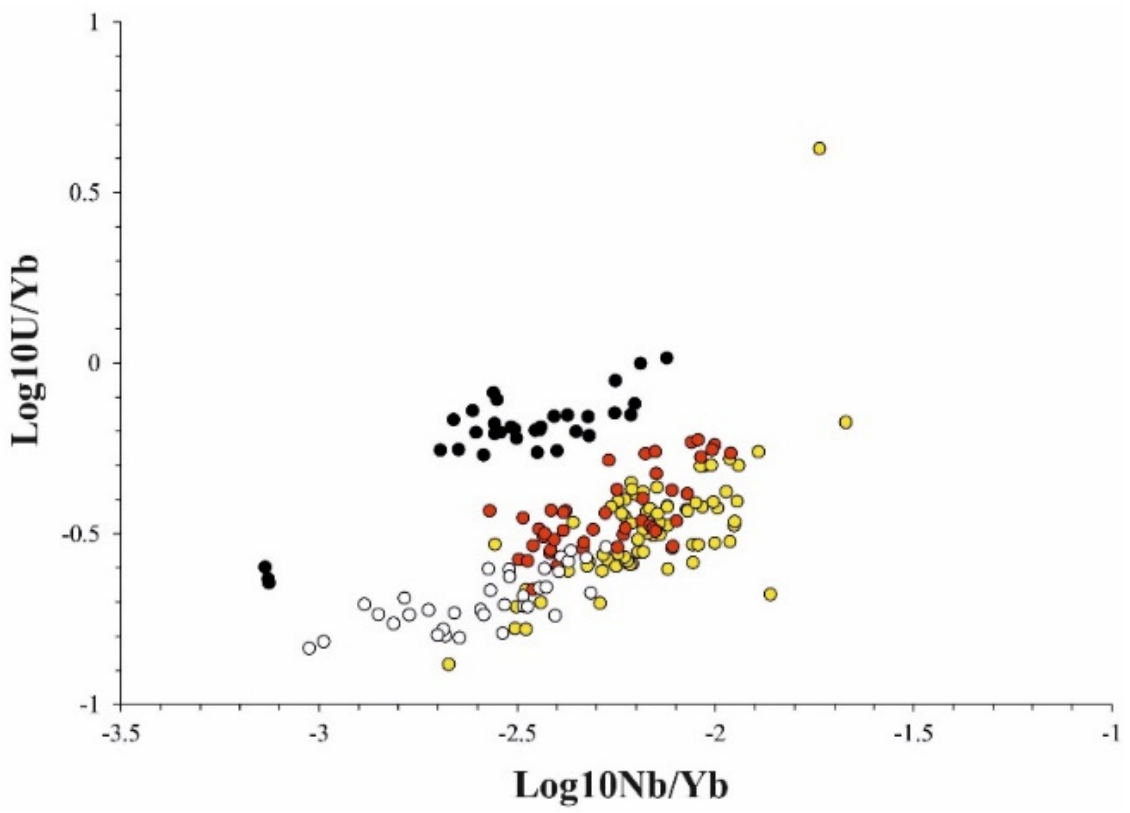

Figure 9. $\log _{10} \mathrm{U} / \mathrm{Yb}$ vs. $\log _{10} \mathrm{Nb} / \mathrm{Yb}$ diagram according to [58]. Symbols as in Figure 7. 

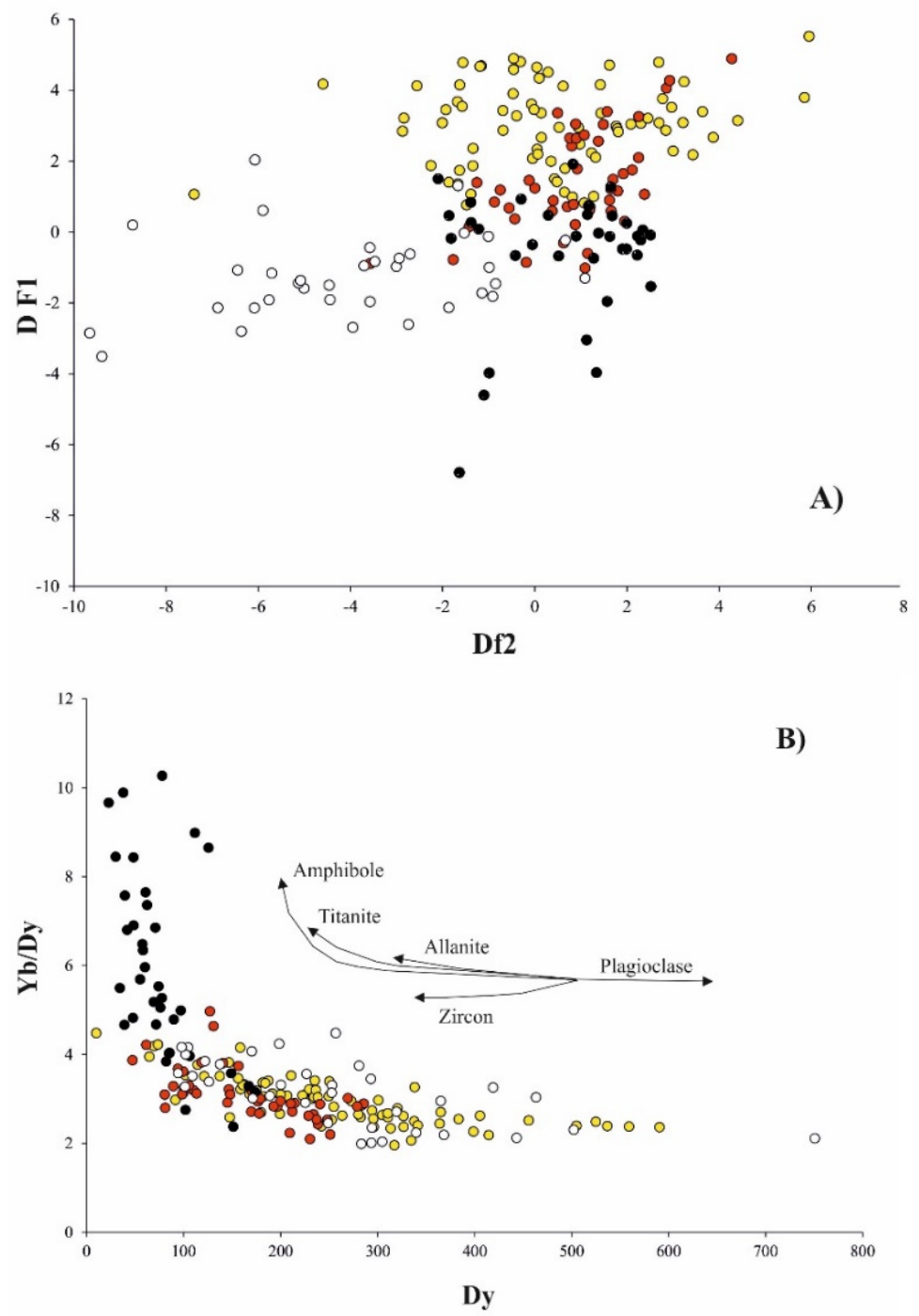

Figure 10. (A) DF1 vs. DF2 and (B) Yb/Dy vs. Dy diagrams according to [58]. Symbols as in Figure 7.

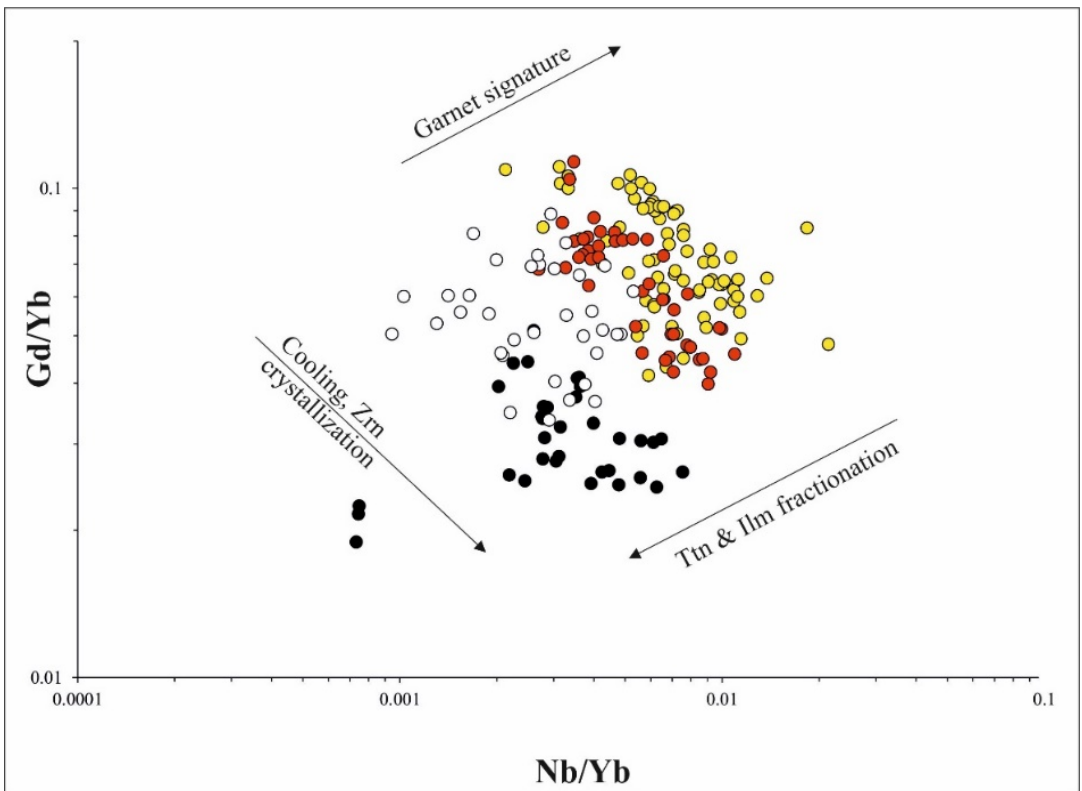

Figure 11. $\mathrm{Gd} / \mathrm{Yb}$ vs. $\mathrm{Nb} / \mathrm{Yb}$ diagram according to [57]. Symbols as in Figure 7. 
Belousova et al. (2002) [27] studied the trace and rare earth elements in igneous zircons from several lithologies. Their classification trees based on recursive partitioning techniques provide a rapid means of relating parent rock type to zircon trace element analysis at confidence levels of $75 \%$ or more. By applying those criteria, zircons from the No Ash level are predominantly (about 70\%) from doleritic affinity rocks; LIK zircons are almost equally subdivided between granitoids with $\mathrm{SiO}_{2}<65 \%$, and granitoids with $\mathrm{SiO}_{2}$ higher than $70-75 \%$, in $4 \mathrm{C}$ and $2 \mathrm{~A}$ levels with more than $50 \%$ of zircons, are assigned to granitoids with $\mathrm{SiO}_{2}$ greater than in the 70-75\% group (Figure 12). In the most recent levels, there are also about $10 \%$ of zircons with a syenitic/monzonitic affinity (Figure 12).

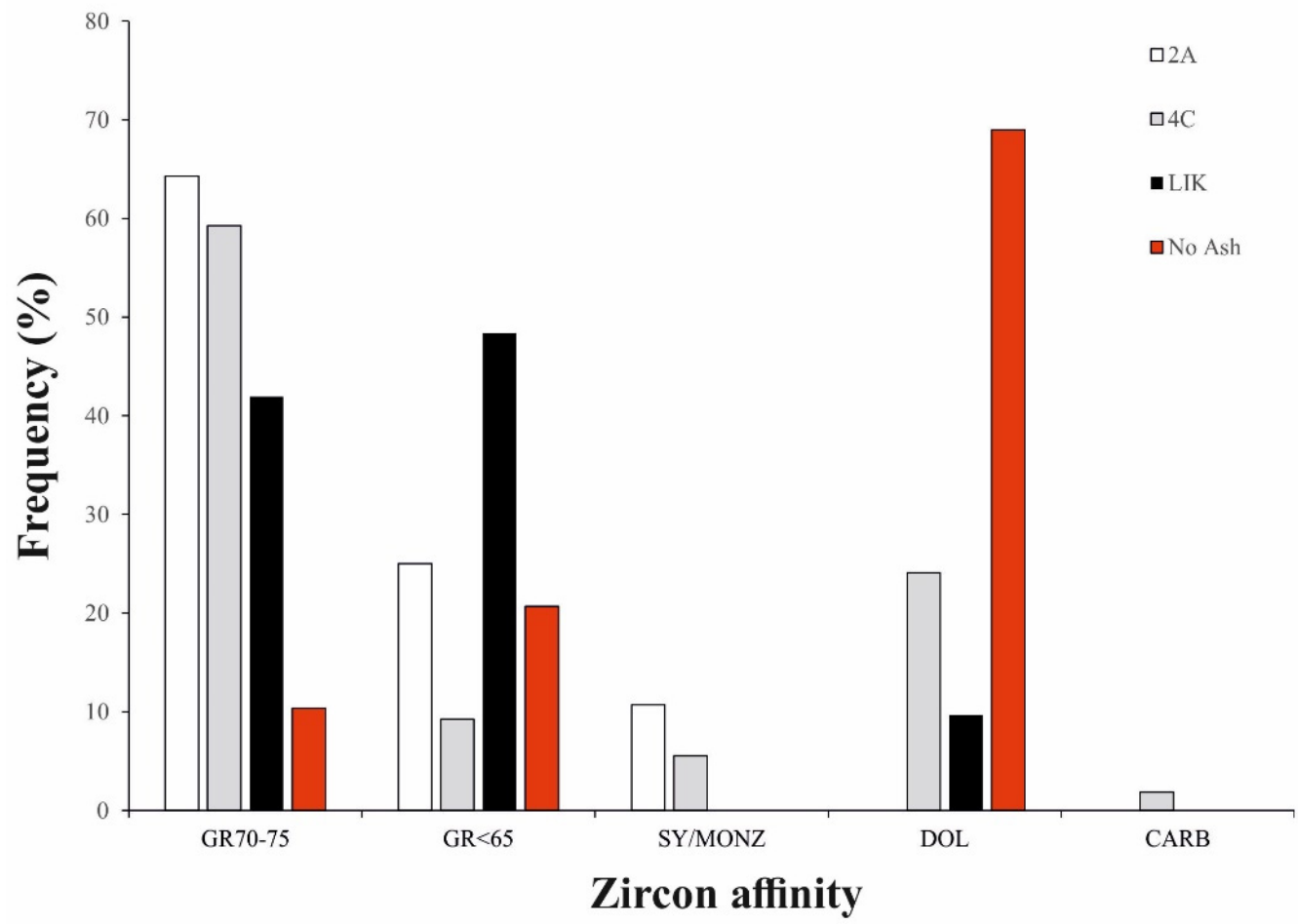

Figure 12. Frequency distributions of zircons according to the possible sources, as determined using the classification tree diagram by [27]. GR70-75: granitoids with about $70-75 \% \mathrm{SiO}_{2}$; GR < 65: granitoids with less than $65 \% \mathrm{SiO}_{2}$; SY /MONZ: syenites and monzonites; DOL: dolerites; CARB: carbonatites.

The temperature of crystallization has been calculated using the Ti-in-zircon geothermometer [59], and a relative density curve has been plotted (Figure 13). No Ash zircons show a smaller gap, and the lowest crystallization temperature among the samples $\left(673-776^{\circ} \mathrm{C}\right)$, while both are similar for Likhall and $4 \mathrm{c}\left(680-839^{\circ} \mathrm{C}\right.$ and $685-857{ }^{\circ} \mathrm{C}$, respectively). Finally, 2 a shows a gap similar to No Ash, but at higher temperatures $\left(703-815^{\circ} \mathrm{C}\right)$. The errors employed for building the relative density curve are arbitrary, and a value of $2 \sigma= \pm 10$ has been chosen, taking into account the number of analyses and the temperature distribution. Even though the diagram shows that the patterns are quite different from each other, many peaks are shared by two or more samples, but with different heights. In particular, the most shared ones are those at $770{ }^{\circ} \mathrm{C}$ (shared by all the samples), and at about $708{ }^{\circ} \mathrm{C}$ (No Ash, Likhall, and 2a), the major parts of the others are shared by two samples (Figure 13). Other than these, $4 \mathrm{c}$ shows little exclusive peaks at $719^{\circ} \mathrm{C}$ and $856{ }^{\circ} \mathrm{C}$, while the one at $815^{\circ} \mathrm{C}$ is rather high, and belongs only to $2 \mathrm{a}$. 


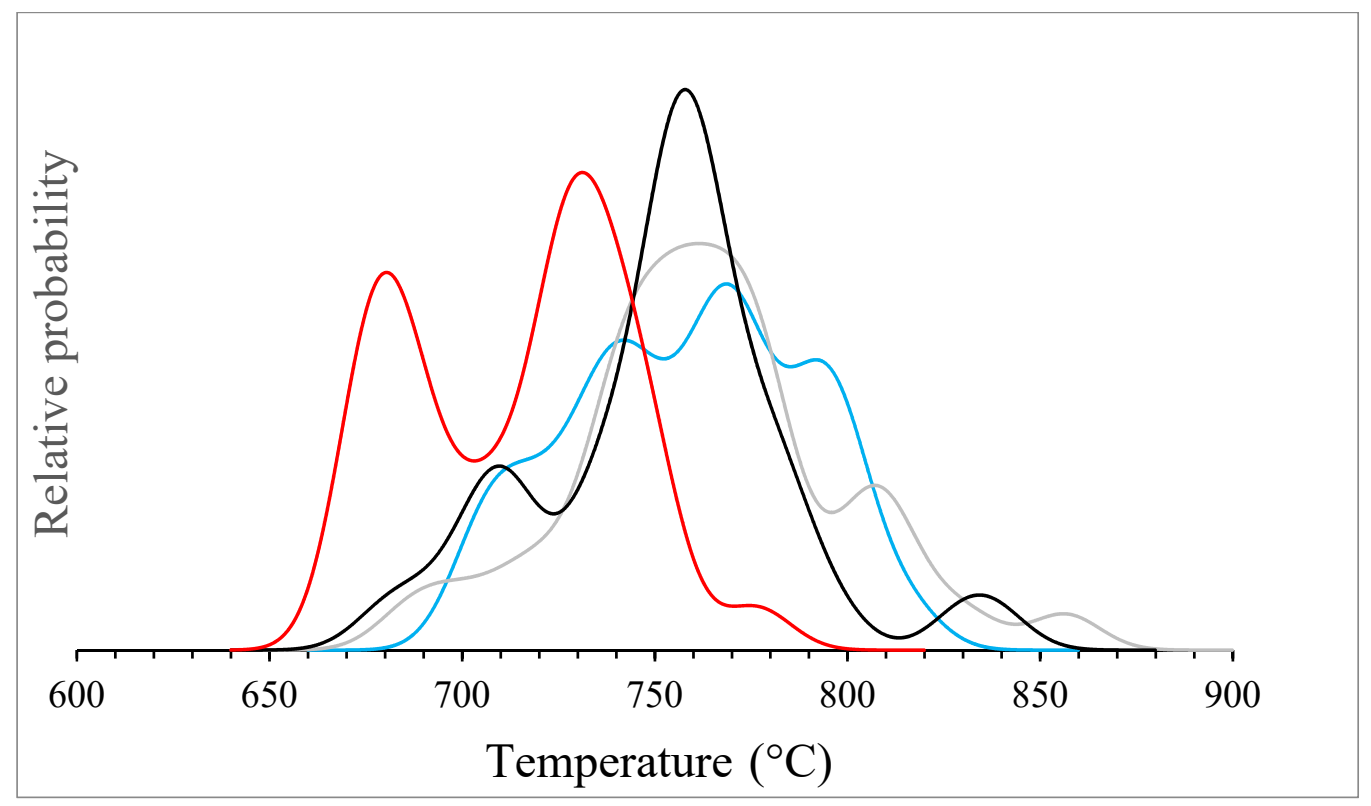

Figure 13. Density curve of zircon crystallization temperatures. Blu line: 2a; grey line: 4c, black line: Likhall; red line: No-ash.

Torsvik and Rehnström (2003) [60] suggested that, during the Late Ordovician, suturing between the Avalonia and Baltica plates closed the Tornquist Sea that had separated these palaeocontinents during most of the Ordovician. This suture zone, the so-called Trans-European Suture Zone, during the Variscan and Alpine orogenesis, further developed and/or rejuvenated, and is now largely concealed by deep sedimentary basins of the late Palaeozoic to Tertiary age. Avalonia separated from Gondwana during the ArenigLlanvirn, however, the exact nature and time of collision between Avalonia and Baltica are not clear in the geological record [60]. In Avalonia, Late Ordovician folding, faulting, and igneous activity is known from the Welsh Borderlands (Shelve area), and may relate to Avalonia-Baltica docking, being more or less coeval with Taconic deformation (455-422 Ma), along the Laurentian margin [61]. Large K-bentonite beds are widespread in Baltica, and the most regionally important is the Kinnekulle bed (Mid-Caradoc age, according to the D. multidensgraptolite zone). The Kinnekulle bed has been dated $452 \pm 2 \mathrm{Ma}$ $\left(\mathrm{U} / \mathrm{Pb}\right.$ zircon age cited in [62]) and $455 \pm 2 \mathrm{Ma}\left({ }^{40} \mathrm{Ar} /{ }^{39} \mathrm{Ar}\right.$ biotite; [63]). According to Huff et al. (1992) [64], this unit shows affinity with granites from the volcanic arc, indicating generation along convergent continental plate margins. Based on the climatic zones, Ref. [60] argued that the Kinnekulle K-bentonite beds could be associated with a Mid-Caradoc calc-alkaline magmatic event in Avalonia. The thickness distribution of these ash beds requires a palaeo-west source area, and the Avalonian magmatic arc is the best candidate to supply Baltica with massive ash falls. According to this reconstruction, Ref. [65] suggested, for zircons found in the "Täljsten" interval at Kinnekulle, that the source volcanoes were probably situated at the west or southwest (present-day directions), where the magmatic activity occurred during the subsequent amalgamation of Baltica, Avalonia, and Laurentia, and [10] endorses the interpretation of [65]. Haynes et al. (2011) [66] studied the biotites present in the Kinnekulle bentonites, and suggested that they are the product of explosive volcanism, with the source magmas having passed through the continental crust on their way to large, single vent eruptions associated with subduction along continental margins like Laurentia-Baltica margins during the Ordovician. However, both the zircons from the ash layer and those from the No Ash layer are slightly older than those previously described [10]. Woodcock et al. (2012) [67] described voluminous back-arc basin volcanism, typically with a bimodal basalt-rhyolite composition, beginning in Welsh basins during the Llanvirn hiatus in arc activity. The back-arc basin volcanism continued after the arc rejuvenated outboard on the microcontinent. The study of $[68,69]$ on the Fishguard Volcanic 
Group in South Wales showed that it represents an example of a volcanic sequence linked to the closure of the Iapetus Ocean. Its age spans in the range 467-458 Ma and reveals that the Fishguard Volcanic Group represents a closely related series of basalts, basaltic andesites, dacites, and rhyolites originating in a back-arc environment. Zircon U-Pb geochronological data for felsic volcanic rocks indicate deposition over a short interval between 465 and 462 Ma. Fritschle et al. (2018) [70] reported arc-related rhyolites from the Avoca volcanic sequence in SE Ireland dated at $463.6 \pm 2.6 \mathrm{Ma}$.

At the same time, Refs. [71-74] showed that the Canadian Appalachians comprise a tectonic collage of Ordovician peri-Laurentian terranes that formed during the closure of the Iapetus Ocean and imbricated beneath the composite margin of Laurentia, and is comprised in the 470-460 Ma interval.

\section{Conclusions}

The literature on detrital zircon presents a lot of age determination, but few analyses of trace elements. Many trace element analyses of non-detrital zircons can be found, however, to our knowledge, there are no analyses of trace elements from what we consider the possible source areas. Commonly, authors using detrital zircons compare the ages while, in past years, Hf isotopes have been used too [75-78]. We think that trace elements could be a new discriminant, because in the same possible source areas, there could be zircons with the same age, but bearing a different trace element fingerprint related to different source rocks. However, the geological setting of the Laurentia and Baltica areas, including the description of basalts to rhyolite association and the presence of ophiolitic slices, makes us confident about the derivation of Kinnekulle zircons and $\mathrm{Cr}$-spinels from those areas.

Author Contributions: Conceptualization, D.L. and B.S.; methodology, M.V. and M.P.; formal analysis, M.V. and M.P.; writing—original draft preparation, D.L. and M.V.; writing-review and editing, D.L., M.V., M.P. and B.S. All authors have read and agreed to the published version of the manuscript.

Funding: This research received no external funding.

Data Availability Statement: The data presented in this study are available on request from the corresponding author.

Acknowledgments: This work was supported with an Advanced Grant from the European Research Council to BS. MP acknowledges the ERNA2 project. Two anonymous reviewers and the editors are kindly acknowledged for their suggestions.

Conflicts of Interest: The authors declare no conflict of interest.

\section{References}

1. Schmitz, B.; Tassinari, M.; Peucker-Ehrenbrink, B. A rain of ordinary chondritic meteorites in the early Ordovician. Earth Planet. Sci. Lett. 2001, 194, 1-15. [CrossRef]

2. Schmitz, B. Extraterrestrial spinels and the astronomical perspective on Earth's geological record and evolution of life. Chem. Erde 2013, 73, 113-135. [CrossRef]

3. Schmitz, B.; Schmieder, M.; Liao, S.; Martin, E.; Terfelt, F. Impact-Crater Ages and Micrometeorite Paleofluxes Compared: Evidence for the Importance of Ordinary Chondrites in the Flux of Meteorites and Asteroids to Earth the Past 500 Million Years; Geological Society of America: Boulder, CO, USA, 2022; Special Papers, in press.

4. Bridges, J.C.; Schmitz, B.; Hutchison, R.; Greenwood, R.C.; Tassinari, M.; Franchi, I.A. Petrographic classification of midOrdovician fossil meteorites from Sweden. Meteorit. Planet. Sci. 2007, 42, 1781-1789. [CrossRef]

5. Greenwood, R.C.; Schmitz, B.; Bridges, J.B.; Hutchison, R.W.; Franchi, I.A. Disruption of the L-chondrite parent body: New oxygen isotope evidence from Ordovician relict chromite grains. Earth Planet. Sci. Lett. 2007, 262, 204-213. [CrossRef]

6. Heck, P.R.; Schmitz, B.; Baur, H.; Wieler, R. Noble gases in fossil micrometeorites and meteorites from 470 Myr old sediments from southern Sweden and new evidence for the L chondrite parent body breakup event. Meteorit. Planet. Sci. 2008, 43, 517-528. [CrossRef]

7. Schmitz, B.; Huss, G.R.; Meier, M.M.M.; Peucker-Ehrenbrink, B.; Church, R.P.; Cronholm, A.; Davies, M.B.; Heck, P.R.; Johansen, A.; Keil, K.; et al. A fossil winonaite-like meteorite in Ordovician limestone: A piece of the impactor that broke up the L-chondrite parent body? Earth Planet. Sci. Lett. 2014, 400, 145-152. [CrossRef]

8. Schmitz, B.; Yin, Q.-Z.; Sanborn, M.E.; Tassinari, M.; Caplan, C.E.; Huss, G.R. A new type of solar-system material recovered from Ordovician marine limestone. Nat. Comm. 2016, 7, 11851. [CrossRef] 
9. Schmitz, B.; Farley, K.A.; Goderis, S.; Heck, P.R.; Bergström, S.M.; Boschi, S.; Claeys, P.; Debaille, V.; Dronov, A.; Van Ginneken, M.; et al. An extraterrestrial trigger for the mid-Ordovician ice age: Dust from the breakup of the L-chondrite parent body. Sci. Adv. 2019, 5, eaax4184. [CrossRef]

10. Liao, S.Y.; Huyskens, M.H.; Yin, Q.-Z.; Schmitz, B. Absolute dating of the L-chondrite parent body breakup with high-precision U-Pb zircon geochronology from Ordovician limestone. Earth Planet. Sci. Lett. 2020, 547, 116442. [CrossRef]

11. Barnes, S.J.; Roeder, P.L. The range of spinel compositions in terrestrial mafic and ultramafic rocks. J. Petrol. 2001, 42, 2279-2302. [CrossRef]

12. Kamenetsky, V.S.; Crawford, A.J.; Meffre, S. Factors controlling chemistry of magmatic spinel: An empirical study of associated olivine, Cr-spinel and melt inclusions from primitive rocks. J. Petrol. 2001, 42, 655-671. [CrossRef]

13. Pober, E.; Faupl, P. The chemistry of detrital spinels and its implications for the geodynamic evolution of the Eastern Alps. Geol. Rund. 1988, 77, 641-670. [CrossRef]

14. Lenaz, D.; Princivalle, F. Crystal-chemistry of detrital chromites in sandstones from Trieste (NE Italy). Neues Jahrb. Miner. Monat. 1996, 429-434.

15. Lenaz, D.; Princivalle, F. The crystal chemistry of detrital chromian spinel from the Southeastern Alps and Outer Dinarides: The discrimination of supplies from areas of similar tectonic setting? Can. Miner. 2005, 43, 1305-1314. [CrossRef]

16. Cookenboo, H.O.; Bustin, R.M.; Wilks, K.R. Detrital chromian spinel compositions used to reconstruct the tectonic setting of provenance: Implications for orogeny in the Canadian Cordillera. J. Sedim. Petrol. 1997, 67, 116-123.

17. Lenaz, D.; Kamenetsky, V.; Crawford, A.J.; Princivalle, F. Melt inclusions in detrital spinel from SE Alps (Italy-Slovenia): A new approach to provenance studies of sedimentary basins. Contrib. Miner. Petrol. 2000, 139, 748-758. [CrossRef]

18. Lenaz, D.; Kamenetsky, V.; Princivalle, F. Cr-spinel supply in Brkini, Istrian and Krk Island flysch basins (Slovenia, Italy and Croatia). Geol. Mag. 2003, 140, 335-372. [CrossRef]

19. Lenaz, D.; Mazzoli, C.; Spišiak, J.; Princivalle, F.; Maritan, L. Detrital Cr-spinel in the Šambron-Kamenica Zone (Slovakia): Evidence for an ocean-spreading zone in the Northern Vardar suture? Int. J. Earth Sci. 2009, 98, 345-355. [CrossRef]

20. Irvine, T.N. Chromian spinel as a petrogenetic indicator. Part 2. Petrologic applications. Can. J. Earth Sci. 1967, 4, 71-103. [CrossRef]

21. Dick, H.J.B.; Bullen, T. Chromian spinel as a petrogenetic indicator in abyssal and alpine-type peridotites and spatially associated lavas. Contrib. Miner. Petrol. 1984, 86, 54-76. [CrossRef]

22. Kamenetsky, V.S. Methodology for the study of melt inclusions in Cr-spinels and implications for parental melts of MORB from FAMOUS areas. Earth Planet. Sci. Lett. 1996, 142, 479-486. [CrossRef]

23. Shimizu, K.; Komiya, T.; Hirose, K.; Shimizu, N.; Maruyama, S. Cr-spinel, an excellent micro-container for retaining primitive melts-Implications for a hydrous plume origin for komatiites. Earth Planet. Sci. Lett. 2001, 189, 177-188. [CrossRef]

24. Shimizu, K.; Shimizu, N.; Komiya, T.; Suzuki, K.; Maruyama, S.; Tatsumi, Y. $\mathrm{CO}_{2}$-rich komatiitic melt inclusions in Cr-spinels within beach sand from Gorgona Island, Colombia. Earth Planet. Sci. Lett. 2009, 288, 33-43. [CrossRef]

25. Heaman, L.M.; Bowins, R.; Crocket, J. The chemical composition of igneous zircon suites: Implications for geochemical tracer studies. Geochim. Cosmochim. Acta 1990, 54, 1597-1607. [CrossRef]

26. Hoskins, P.W.O.; Ireland, T.R. Rare Earth Element chemistry of zircon and its use as a provenance indicator. Geology 2000, 28, 627-630. [CrossRef]

27. Belousova, E.A.; Griffin, W.L.; O'Reilly, S.Y.; Fisher, N.L. Igneous zircon: Trace element composition as an indicator of source rock type. Contrib. Miner. Petrol. 2002, 143, 602-622. [CrossRef]

28. Owen, M.R. Hafnium content of detrital zircons, a new tool for provenance study. J Sedim. Petrol. 1987, 57, 824-830.

29. Vavra, G.; Schmid, R.; Gebauer, D. Internal morphology, habit and U-Th-Pb microanalysis of amphibolite-to-granulite facies zircons: Geochronology of the Ivrea Zone (Southern Alps). Contrib. Miner. Petrol. 1999, 97, 205-217. [CrossRef]

30. Hartmann, L.A.; Leite, J.A.D.; Silva, I.C.; Remus, M.V.D.; McNaughton, N.J.; Groves, D.I.; Fletcher, I.R.; Santos, J.O.S.; Vasconcellos, M.A.Z. Advances in SHRIMP geochronology and their impact on understanding the tectonic and metallogenic evolution of southern Brazil. Aust. J. Earth Sci. 2000, 47, 829-844. [CrossRef]

31. Hoskins, P.W.O.; Shaltegger, U. The Composition of Zircon and Igneous and Metamorphic Petrogenesis. Rev. Miner. Geochem. 2003, 53, 27-62. [CrossRef]

32. Corfu, F.; Hanchar, J.M.; Hoskin, P.W.; Kinny, P. Atlas of zircon textures. Rev. Miner. Geochem. 2003, 53, 469-500. [CrossRef]

33. Galeotti, S.; Sahy, D.; Agnini, C.; Condon, D.; Fornaciari, E.; Francescone, F.; Giusberti, L.; Pälike, H.; Spofforth, D.J.; Rio, D. Astrochronology and radio-isotopic dating of the Alano di Piave section (NE Italy), candidate GSSP for the Priabonian stage (late Eocene). Earth Planet. Sci. Lett. 2019, 525, 115746. [CrossRef]

34. Jarosewich, E.; Nelen, J.A.; Norberg, J.A. Reference samples for electron microprobe analysis. Geostand. Newsl. 1980, 4 , 43-47. [CrossRef]

35. Petrelli, M.; Laeger, K.; Perugini, D. High spatial resolution trace element determination of geological samples by laser ablation quadrupole plasma mass spectrometry: Implications for glass analysis in volcanic products. Geosci. J. 2016, 20, 851-863. [CrossRef]

36. Petrelli, M.; Morgavi, D.; Vetere, F.; Perugini, D. Elemental imaging and petro-volcanological applications of an improved laser ablation inductively coupled quadrupole plasma mass spectrometry. Period. Miner. 2016, 85, 25-39.

37. Longerich, H.P.; Jackson, S.E.; Günther, D. Inter-laboratory note. Laser ablation inductively coupled plasma mass spectrometric transient signal data acquisition and analyte concentration calculation. J. Anal. At. Spectrom. 1996, 11, 899-904. [CrossRef] 
38. Maibam, B.; Lenaz, D.; Foley, S.; Berndt, J.; Belousova, E.; Wangjam, M.; Goswami, J.N.; Kapsiotis, A. U-Pb and Hf isotope study of detrital zircon and $\mathrm{Cr}$-spinel in the Banavara quartzite and implications for the evolution of the Dharwar Craton, south India. Geol. Mag. 2021, 158, 1671-1682. [CrossRef]

39. Alwmark, C.; Schmitz, B. Extraterrestrial chromite in the resurge deposits of the early Late Ordovician Lockne crater, central Sweden. Earth Planet. Sci. Lett. 2007, 253, 291-303. [CrossRef]

40. Lenaz, D.; Princivalle, F.; Schmitz, B. First crystal-structure determination of chromites from an acapulcoite and ordinary chondrites. Miner. Mag. 2015, 79, 755-765. [CrossRef]

41. Derbyshire, E.J.; O’Driscoll, B.; Lenaz, D.; Zanetti, A.; Gertisser, R. Chromitite petrogenesis in the mantle section of the Ballantrae Ophiolite Complex (Scotland). Lithos 2019, 344-345, 51-67. [CrossRef]

42. Derbyshire, E.J.; O'Driscoll, B.; Lenaz, D.; Gertisser, R.; Kronz, A. Compositionally heterogeneous podiform chromitite in the Shetland Ophiolite Complex (Scotland): Implications for chromitite petrogenesis and late-stage alteration in the upper mantle portion of a supra-subduction zone ophiolite. Lithos 2013, 162-163, 279-300. [CrossRef]

43. O'Driscoll, B.; Leuthold, J.; Lenaz, D.; Skogby, H.; Day, J.M.D.; Adetunji, J. Melt Percolation, Melt-Rock Reaction and Oxygen Fugacity in Supra-Subduction Zone Mantle and Lower Crust from the Leka Ophiolite Complex, Norway. J. Petrol. 2021, 62, 1-26. [CrossRef]

44. Garuti, G.; Zaccarini, F.; Moloshag, V.; Alimov, V. Platinum Group Minerals as indicators of sulfur fugacity in ophiolitic upper mantle: An example from chromitites of the Ray-Iz ultramafic complex, Polar Urals, Russia. Can. Miner. 1999, 37, $1099-1115$.

45. Garuti, G.; Pushkarev, E.V.; Thalhammer, O.A.R.; Zaccarini, F. Chromitites of the Urals (Part 1): Overview of chromite mineral chemistry and geo-tectonic setting. Ofioliti 2012, 37, 27-53.

46. Zakrzewski, M. Chromian spinels from Kuså, Bergslagen, Sweden. Am. Miner. 1989, 74, 448-455.

47. Clos, F.; Gilio, M.; van Roermund, H.L.M. Fragments of deeper parts of the hanging wall mantle preserved as orogenic peridotites in the central belt of te Seve Nappe Complex, Sweden. Lithos 2014, 192-195, 8-20. [CrossRef]

48. O'Driscoll, B.; Walker, R.J.; Day, J.M.D.; Ash, R.D.; Daly, J.S. Generations of melt extraction, melt-rock interaction and high-temperature metasomatism preserved in peridotites of the 497 Ma Leka ophiolite complex. J. Petrol. 2015, 56, 1797-1828. [CrossRef]

49. Hanski, E.J.; Kamenetsky, V.S. Chrome spinel-hosted melt inclusions in Paleoproterozoic primitive volcanic rocks, northern Finland: Evidence for coexistence and mixing of komatiitic and picritic magmas. Chem. Geol. 2013, 343, 25-37. [CrossRef]

50. Alapieti, T.T.; Kujanpaa, J.; Lahtinen, J.J.; Papunen, H. The Kemi stratiform chromitite deposit, Northern Finland. Econ. Geol. 1989, 84, 1057-1077. [CrossRef]

51. Malpas, J.; Strong, D.F. A comparison of chrome-spinels in ophiolites and mantle diapirs of Newfoundland. Geochim. Cosmochim. Acta 1975, 39, 1045-1060. [CrossRef]

52. Colman-Sadd, S.P.; Dunning, G.R.; Dec, T. Dunnage-Gander relationships and Ordovician orogeny in central newfoundland: A sediment provenance and U/Pb age study. Am. J. Sci. 1992, 292, 317-355. [CrossRef]

53. Lenaz, D.; Schmitz, B.; Alvarez, W. The terrestrial Cr-spinels in the Maiolica limestones: Where are they from? In $250 \mathrm{Million}$ Years of Earth History in Central Italy: Celebrating 25 years of the Geological Observatory of Coldigioco; Koeberl, C., Bice, D.M., Eds.; Geological Society of America: Boulder, CO, USA, 2019; Volume 542, pp. 121-131.

54. Harley, S.L.; Kelly, N.M.; Möller, A. Zircon behavior and the thermal histories of mountain chains. Elements 2007, 3, 31-36. [CrossRef]

55. Grimes, C.B.; Wooden, J.L.; Cheadle, M.J.; John, B.E. "Fingerprinting" tectono-magmatic provenance using trace elements in igneous zircon. Contrib. Miner. Petrol. 2015, 158, 757-783. [CrossRef]

56. Rubatto, D. Zircon: The Metamorphic Mineral. Rev. Miner. Geochem. 2017, 83, 261-295. [CrossRef]

57. Grimes, C.B.; John, B.E.; Kelemen, P.B.; Mazdab, F.K.; Wooden, J.L.; Cheadle, M.J.; Hanghøj, K.; Schwartz, J.J. Trace element chemistry of zircons from oceanic crust: A method for distinguishing detrital zircon provenance. Geology 2007, 35, 643-646. [CrossRef]

58. Lukács, R.; Guillong, M.; Bachmann, O.; Fodor, L.; Harangi, S. Tephrostratigraphy and Magma Evolution Based on Combined Zircon Trace Element and U-Pb Age Data: Fingerprinting Miocene Silicic Pyroclastic Rocks in the Pannonian Basin. Front. Earth Sci. 2021, 9, 615768. [CrossRef]

59. Watson, E.B.; Wark, D.A.; Thomas, J.B. Crystallization thermometers for zircon and rutile. Contrib. Miner. Petrol. 2006, 151, 413. [CrossRef]

60. Torsvik, T.H.; Rehnström, E.F. The Tornquist sea and Baltica-Avalonia docking. Tectonophysics 2003, 362, 67-82. [CrossRef]

61. Robinson, P.; Tucker, R.D.; Bradley, D.; Berry, H.N.; Berry, I.V.; Osberg, P.H. Palaeozoic orogens in New England, USA. Geol. Fören. Förh 1998, 120, 119-148.

62. Tucker, R.D.; McKerrow, W.S. Early Palaeozoic chronology: A review in light of new U-Pb zircon ages from Newfoundland and Britain. Can. J. Earth Sci. 1995, 32, 368-379. [CrossRef]

63. Min, K.; Renne, P.R.; Huff, W.D. ${ }^{40} \mathrm{Ar} /{ }^{39}$ Ar dating of Ordovician K-bentonites in Laurentia and Baltoscandia. Earth Planet. Sci. Lett. 2001, 185, 121-134. [CrossRef]

64. Huff, W.D.; Bergström, S.M.; Kolata, D.R. Gigantic Ordovician volcanic ash fall in North America and Europe: Biological, tectonomagmatic, and event-stratigraphic significance. Geology 1992, 20, 875-878. [CrossRef] 
65. Lindskog, A.; Costa, M.; Rasmussen, C.Ø.; Connelly, J. Refined Ordovician timescale reveals no link between asteroid breakup and biodiversification. Nat. Comm. 2017, 8, 14066. [CrossRef]

66. Haynes, J.T.; Huff, W.D.; Melson, W.G. Major Ordovician tephras generated by caldera-forming explosive volcanism on continental crust: Evidence from biotite compositions. In Ordovician of the World. Cuadernos del Museo Geominero; Gutiérrez-Marco, J.C., Rábano, I., García-Bellido, D., Eds.; Instituto Geológico y Minero de España: Madrid, Spain, 2011; Volume 14, pp. $229-235$. ISBN 978-84-7840-857-3.

67. Woodcock, N.H. Ordovician Volcanism and Sedimentation on Eastern Avalonia. In Geological History of Britain and Ireland, 2nd ed.; Woodcock, N., Strachan, R., Eds.; Blackwell Publishing Ltd.: Hoboken, NJ, USA, 2012.

68. Phillips, B.A.; Kerr, A.C.; Bevins, R. A re-appraisal of the petrogenesis and tectonic setting of the Ordovician Fishguard Volcanic Group, SW Wales. Geol. Mag. 2016, 153, 410-425. [CrossRef]

69. Bevins, R.; Atkinson, N.; Ixer, R.; Evans, J. U-Pb zircon age constraints for the Ordovician Fishguard Volcanic Group and further evidence for the provenance of the Stonehenge bluestones. J. Geol. Soc. 2017, 174, 14-17. [CrossRef]

70. Fritschle, T.; Daly, J.S.; McConnell, B.; Whitehouse, M.J.; Menuge, J.F.; Buhre, S.; Mertz-Kraus, R.; Döpke, D. Peri-Gondwanan Ordovician arc magmatism in southeastern Ireland and the Isle of Man: Constraints on the timing of Caledonian deformation in Ganderia. GSA Bull. 2018, 130, 1918-1939. [CrossRef]

71. Schoonmaker, A.; Kidd, W.S.F.; DeLong, S.E.; Bender, J.F. Lawrence Head Volcanics and Dunnage Mélange, Newfoundland Appalachians: Origin by Ordovician Ridge Subduction or in Back-Arc Rift? Geosci. Can. 2014, 41, 523-556. [CrossRef]

72. Zagorevski, A.; van Staal, C.R.; McNicoll, V.; Lissenberg, C.J.; Valverde-Vaquero, P. Lower to Middle Ordovician evolution of peri-Laurentian arc and backarc complexes in Iapetus: Constraints from the Annieopsquotch accretionary tract, central Newfoundland. GSA Bull. 2006, 118, 324-342. [CrossRef]

73. Zagorevski, A.; van Staal, C.R.; McNicoll, V.; Rogers, N. Upper Cambrian to Upper Ordovician peri-Gondwanan island arc activity in the Victoria lake supergroup, central Newfoundland: Tectonic development of the Northern Ganderian margin. Am. J. Sci. 2007, 307, 339-370. [CrossRef]

74. Zagorevski, A.; McNicoll, V.; Rogers, N.; van Hees, G.H. Middle Ordovician disorganized arc rifting in the peri-Laurentian Newfoundland Appalachians: Implications for evolution of intra-oceanic arc systems. J. Geol. Soc. 2016, 173, 76-93. [CrossRef]

75. Brennan, D.T.; Link, P.K.; Li, Z.-H.; Martin, L.; Johnson, T.; Evans, N.J.; Li, J. Closing the "North American Magmatic" gap: Crustal evolution of the Clearwater Block from multi-isotope and trace element zircon data. Precambrian Res. 2022, 369, 106533. [CrossRef]

76. Liu, H.; McKenzie, N.R.; Colleps, C.L.; Chen, W.; Ying, Y.; Stockli, L.; Sardsud, A.; Stockli, D.F. Zircon isotope-trace element compositions track Paleozoic-Mesozoic slab dynamics and terrane accretion in Southeast Asia. Earth Planet. Sci. Lett. 2022, 578, 117298. [CrossRef]

77. Marchese Rizzi, M.A.; Dillenburg, S.R.; Takehara, L.; Girelli, T.J.; Wust, C.F.; Lana, C.D.C.; Chemale Junior, F. Andean fingerprint on placer sand from the southern Brazilian coast. Sedim. Geol. 2022, 428, 106061. [CrossRef]

78. Zeh, A.; Wilson, A.H. U-Pb-Hf isotopes and shape parameters of zircon from the Mozaan Group (South Africa) with implications for depositional ages, provenance and Witwatersrand-Pongola Supergroup correlations. Precambrian Res. 2022, 368, 10. [CrossRef] 